\title{
EFFECT OF ANHYDROUS-AMMONIA INJECTION ON PLANT AND SOIL MICRO-ORGANISMS BIOLOGICAL ACTIVITIES
}

\author{
W. F. EL Metwally ${ }^{1}$ and T. A. El-Sakhawy ${ }^{2}$
}

\begin{abstract}
\end{abstract}
Agricultural practices such as seedbed preparation systems and fertilization especially Anhydrous-Ammonia had a great impact on plant and soil microbial community which were sensitive indicators of changes in soil. A field experiment was carried out at the research farm of Rice Mechanization Center (RMC), Meet El-Deyba, Kafr El-Sheikh Governorate, during growing the winter wheat season 2015-2016 to study the interaction effect of anhydrous-ammonia injection and seedbed preparation systems on wheat growth/yield and soil micro-organisms biological activities. Anhydrous-Ammonia was injected in soil with two levels, of $75 \mathrm{Kg} \mathrm{N} / \mathrm{fed}$ (A.A.1), and $94 \mathrm{Kg} \mathrm{N} / \mathrm{fed}$ (A.A.2) which represent $100 \%$ and $125 \%$ of nitrogen recommended dose and granulated urea, (control) $46.5 \%$ at three doses according to agronomy recommendations. While, the applied seedbed preparation systems were Heavy system, HS (Moldboard plough one pass followed by Chisel plough twice and laser leveling), Moderate system, MS (Chisel plough one pass followed by Rotary twice and laser leveling) and Conventional system, CS (Chisel plough twice and wooden leveling). However, the used different wheat cultivars were Gemmiza lland Shandweel. Soil micro-organism biological activity, wheat plant growth activity and wheat yield and its components were measured and determined to realize the objective of this investigation. The Soil micro-organism biological activity and wheat plant growth activity were done at different three times of 4 days, 1 month after Anhydrous-Ammonia injection and after wheat crop harvesting. The obtained results indicated that:

- The population and activity of soil micro-organisms increased as the length of time increased compared with applied Urea fertilizer. Approximately, one month after A.A.1 injection, the populations of a

\footnotetext{
${ }^{1}$ Researcher, Agric. Eng. Res. Inst., Agric. Res. Center.

${ }^{2}$ Assistant Researcher, Soil, Water and Environmental Res. Inst.; Agric. Res. Center.
} 
bacterial group were increased by an average of 57.8 and $58.6 \%$ while, the fungi group was increased by an average of 53.5 and $55.2 \%$ compared with 65.1 and $66.0 \%$ for actinomycetes group during growing Gemmiza 11 and Shandweel wheat cultivars, respectively.

- Using MS seedbed preparation system gave the highest values of the total grain yield of 18.5, 29.6 and $24.1 \mathrm{Ardb} / \mathrm{Fed}$. were obtained for Gemmiza wheat cultivars compared with 17, 24.8 and $20.3 \mathrm{Ardb} / \mathrm{Fed}$. for Shandweel wheat cultivars under applied fertilizer levels of Urea, A.A.1 and A.A.2, respectively.

- Finally, from mentioned above and analyses of yield and its components, the authors recommended the wheat farmers in Egypt using MS seedbed preparation system and applied fertilizer level A.A.1 to get high wheat yield and maintain the soil in a good biological state.

\section{INTRODUCTION}

Across recent decades many of the scientific literature reported that the plant roots grow in a complex environment containing billions of soil organisms, such as bacteria and fungi. Most of the mineral fertilizers which added to soil consist of concentrated soluble nutrients that will impact short-term microbial activity. Soil biological processes are responsible for supplying approximately $65 \%$ of the available phosphorus in the soil and $75 \%$ of the plant available nitrogen. They play a crucial role in promoting plant health, water dynamics and maintaining an adequate supply of plant nutrients for crop growth. Some of the processes soil organisms contribute to nutrient retention, nutrient cycling, waterholding capacity and water infiltration, degradation of pollutants, and disease suppression. They also increase the biological diversity of the soil and improve soil structure. Like all organisms, there are many factors had impacts on soil environment or food sources of soil microorganisms such as time of adding fertilizers, soil temperature, soil $\mathrm{pH}$, a prevalence of food source and other factors such as time between fertilizer patches, rate, formulation of fertilizer, and depth of adding fertilizer to soil. The biological parameters have great value as early and sensitive indicators due to changes in soil properties by different management strategies such 
as tillage and fertilization. The number of populations of microorganisms in soil was significantly higher under reduced tillage with average percentage ranged from 20 to $30 \%$ than under conventional tillage in both depths ranges 0-15 and 15-30 cm.(Buunemann and Mc Neil 2004; Mijangos et al., 2005; Gajda (2008); Lupway et al., 2010; Benke et al., 2012; Coyne and Mikkelsen, 2015).

One of the main targets of the conservation tillage systems is to ensures that organic matter accumulates near the soil surface due to maintain crop residue on the soil. The accumulation of organic matter providing the microbes with energy in the form of carbon compounds and increases soil microbial activity. However, the microbial activity tends to be slower in conservation tillage systems than that obtained into the soil by conventional tillage. In addition tillage collapses the pores and changes the water holding, gas, and nutrient exchange capacity of the soil. Reducing soil disturbance increases the diversity and population of soil organisms. These soils release nutrients gradually and have better soil structure than full width tillage systems (The Pennsylvania State University Annual Brochure, 1996 ).

The interaction of tillage and $\mathrm{N}$ rate of two $\mathrm{N}$ sources had a significant effect on plant $\mathrm{P}$ and $\mathrm{N}$ uptake, especially at the early growth stages with both $\mathrm{N}$ sources. Moreover, the less disturbing tillage systems enhanced to increase about $15-40 \%$ in the soil biological activity, on average, than conventional tillage system. Microbial biomass $\mathrm{N}$ and $\mathrm{C}$ content, activity of dehydrogenase and arylsulfatase, fluorescein diacetate hydrolysis and microbial respiration rate are considered as an useful indicators of soil quality and sensitivity parameters of soil biological activity to tillage applied in monitoring all conditions alter soil environment(Al-Kaisi and Kwaw-Mensah, 2007; Gajda et al., 2013).

Many researchers studied the importance of nitrogen fertilizer for plants and its interaction effects between soil micro-organisms activities and plant growth. Its results concluded that the nitrate $\mathrm{No}_{3}$ and ammonium $\mathrm{NH}_{4}$ are the main inorganic nitrogen sources taken up by roots of higher plants. Upon uptake, $\mathrm{NO}_{3}$ can be reduced either within the shoot or root and excess amounts can be stored in different plant tissues like vacuoles. Because of its toxicity effects on crops when taken up in large amounts, 
$\mathrm{NH}_{4}$ is normally assimilated within the roots. Crops fertilized by $\mathrm{NH}_{4}$ should be capable of regulating both external and internal acidic $\mathrm{pH}$ to avoid 'ammonia syndrome' resulting from ionic imbalances. However, mixed $\mathrm{N}$ nutrition occurring in the presence of both $\mathrm{NH}_{4}$ and $\mathrm{NO}_{3}$ is capable of supporting better crop growth than sole application of either $\mathrm{N}$ (Barry et al., 1990; Cramer and Lewis, 1993; Marschner, 1995; Gerendas et al.,1997; Mehrer and Mohr,1989 and Britto and Kronzucker, 2002).

Urea and anhydrous ammonia are good $\mathrm{N}$ fertilizer sources. The injury of anhydrous ammonia and urea can be reducing by applying with good injection depth, good soil conditions and proper management. Sawyer (2010). The anhydrous ammonia $\mathrm{NH}_{3}$ (A.A.) is one of most inexpensive, commercially available $\mathrm{N}$ fertilizers. This product is a flammable and toxic alkaline gas that is stored as a liquefied gas. Injection of anhydrous ammonia (A.A.) into soil causes high ammonia concentrations and high $\mathrm{pH}$ in the retention zone of ammonia around the point of injection. These conditions might increase erosion and decrease soil productivity because they can cause loss of soil structural stability, hydrolysis of organic $\mathrm{C}$ and inhibition of microbial activity. Also, It cause an initial loss of wet aggregate stability in the $\mathrm{NH}_{3}$ retention zone, but this loss is likely to be recovered when microbial activity resumes(Miller and Cramer, 2004 and Kumar and Maiti, 2013).

Inorganic fertilizers had a positive or negative effect on soil microorganisms. Also, those effects on soil microorganisms described as direct or short-term impacts due to contact with inorganic fertilizer however, indirect or long-term effects caused by the chemical changes for the soil environment or food sources of soil microorganisms. A drastic reduction in soil bacteria was shown in soil sampled on the day of application, but the populations did not go to zero. As the length of time increased after application, there was an increase in the bacterial population in comparison with the injection zone that had no A.A. applied in it. Approximately five weeks after ammonia injection, there were no major differences in the bacteria number between the sets of plots, which had either 0 or $100 \mathrm{Ib}$ N/A applied. While, the effect A.A. had on soil fungi was a bit more long lasting than with the bacteria. This effect is still 
being a net negative effect in the row at 31 days after application (Gupta, 2016 and Vitosh 2017).

The wheat yield responses to applied nitrogen $(\mathrm{N})$ were small or negative in a drought but larger (17 kg grain $\left.\mathrm{kg}^{-1} \mathrm{Nfertilizer}\right)$ in favorable seasons. There was no consistent difference between A.A. and urea effects on yield, grain protein or efficiency of fertilizer-N recovery, and there were no consistent differences arising from banding depth or application time. Anhydrous ammonia and urea caused transient changes in microbial activity and populations within fertilizer bands, but both products had little effect on microbes in the soil between the bands. The longest lasting effect was on microbial diversity, which remained low at 7 months after A.A. banding (Hossein and Gooshch, 2013and Angus et al.; 2014).

Nowadays, the use of Anhydrous-Ammonia in fertilizing wheat crop was recommended under Egyptian conditions and its application area going to increase year by year. Increasing $\mathrm{N}$ levels significantly increased each of spike length, 1000-grain weight and grain and straw yields of wheat plants due to increasing nitrogen level up to $105 \mathrm{~kg} \mathrm{~N} / \mathrm{fed}$ (Abd ElHmeed and Omar, 2006; Mahmoud et al., 2006 and Abdelkhalek et al.,2015). Therefore, the main target of this investigation is to study the interaction effect of different seedbed preparation systems and anhydrousammonia injection on wheat plant growth/yield and soil micro-organisms activities.

\section{MATERIALS AND METHODS}

\subsection{Experimental Field Layout}

The experimental field was carried out at the research farm of Rice Mechanization Center (RMC), Meet El-Deyba, Kafr El-Sheikh Governorate during growing the winter wheat season of 2015. The experiment was established as split-split plot design with three factors at three replicates. Frist factor of seedbed preparation system was assigned to main plots with three levels, the second factor of fertilization was assigned to split plot with three levels however, the third factor was two wheat cultivars (Gemmiza 11 and Shandweel) which were assigned to sub-split plots. The experimental field area was 2.3 Fedden $(103 \mathrm{~m} * 94 \mathrm{~m})$ which were divided into 54 equal plots. The soil mechanical analysis, soil acidity $(\mathrm{pH})$ and electric conductivity (EC) of experimental field were 
done in the soil science lab. of the Agricultural Faculty, Kafr El-Sheikh University as shown in the Table (1).

Table (1): Soil mechanical analysis, acidity $(\mathrm{pH})$ and electric conductivity (EC) of experimental field.

\begin{tabular}{|c|c|c|c|c|c|c|}
\hline \multirow{2}{*}{ Soil depth, cm } & \multicolumn{3}{|c|}{ Soil mechanical analysis } & \multirow{2}{*}{$\begin{array}{c}\text { Soil } \\
\text { texture }\end{array}$} & \multirow{2}{*}{ EC } & \multirow{2}{*}{$\mathrm{pH}$} \\
\cline { 2 - 5 } & Sand,\% & Silt, \% & Clay,\% & & \\
\hline $0-20$ & 34.4 & 18.5 & 47.1 & Clay & \multirow{3}{*}{3.6} & \multirow{2}{*}{8.77} \\
\hline $20-40$ & 40.4 & 20.5 & 39.1 & Clay & \\
\hline $40-60$ & 47.9 & 10.5 & 41.6 & Clay & & \\
\hline
\end{tabular}

\subsection{Study Parameters:-}

The experiment was arranged in split-split plot design as fallowed. a- Main plots were used for seedbed preparation system as follow:

- Heavy system, (HS):Moldboard plough one pass followed by Chisel plough twice and laser leveling,

- Moderate system, (MS): Chisel plough one pass followed by Rotary twice and laser leveling,

- Conventional system, (CS): Chisel plough twice and wooden leveling.

b- Sub-main plots which act Fertilization levels with AnhydrousAmmonia and urea:

- Urea- fertilization with Granulated urea $46.5 \%$ at three doses with total $75 \mathrm{~kg} \mathrm{~N} / \mathrm{fed}$,

- A.A.1- fertilization with $75 \mathrm{~kg} \mathrm{~N} /$ fed of Anhydrous-Ammonia with 80\% Nitrogen,

- A.A.2- fertilization with $93.75 \mathrm{~kg} \mathrm{~N} /$ fed of Anhydrous Ammonia with $80 \%$ Nitrogen.

c- Sub-sub plots which act two wheat cultivars of Gemmiza 11and Shandweel.

The anhydrous ammonia was injected into the soil after seedbed preparation as well as granule urea was applied with suggested levels mentioned above and creeping using wooden leveler to maintain anhydrous ammonia inside soil. The injected soil was left for 4 days and drilled with recommended rate of wheat grains with both wheat cultivars of (Gemmiza 11 and Shandweel) under study.

\subsection{Study Measurements:-}

To realize the main objective of this investigation at any given study parameters, three different groups of measurements were done as follows: 
$\mathbf{1}^{\text {st }}$ group: Soil micro-organism biological activity by counting the number of soil bacteria, fungi, and Actinomycetes.

$2^{\text {nd }}$ group: Determining the nitrogen content in soil and wheat plant.

$3^{\text {rd }}$ group: Wheat yield and its components and harvest index.

The Soil micro-organism biological activity and wheat plant growth activity were done at different three times of 4 days, 1 month after Anhydrous-Ammonia injection and after wheat crop harvesting.

\subsubsection{Collection of the soil samples.}

Soil sample were taken at three times during wheat growing season. Frist time was immediately after anhydrous ammonia injection or urea applying, second time was after 1 month from planting, and last time was after harvesting time. Three soil samples were randomly collected from different places inside each replicate to give a representative soil samples to a depth of $0-10 \mathrm{~cm}$ and mixed together to give a composite sample. After that it were transported to the laboratory. All samples of soils were air-dried at room temperature for $48 \mathrm{~h}$, sieved to $<2 \mathrm{~mm}$, and stored at room temperature for estimation and microbiological analysis at Sakha Microbiological lab, Soil, Water and Environmental Res. Inst., Kafr ElSheikh Governorate.

\subsubsection{Determination of soil microorganisms activities.}

The biological activity of microorganism was assayed by plate count technique using specific media for each group of soil. The total count of microorganisms was determined using soil extract agar for Bactria, Martin's medium for Fungi and Jensen's medium for counting soil actinomycetes (Allen, 1959).

\subsubsection{Determination of nitrogen in soil and in plant.}

Available nitrogen in soil was extracted by $1.0 \mathrm{M} \mathrm{K}_{2} \mathrm{SO}_{4}$ and determined by $\mathrm{Mg} \mathrm{O}$ and devarda alloy using the same collected soil samples for microbiological analysis according to Kjeldahl method Jackson (1967). For determination of nitrogen content in plant materials were digested as described by Chapman and Pratt (1960). The digested materials were distilled by Microkjeldahl method and the nitrogen content (\%) of distillate was determined by titration according Black et al. (1965).

\subsubsection{Crop yield, its components and crop index}

Total obtained grain yield for each variable under study was determined and calculated by $\mathrm{kg} /$ Fedden. Also, yield component such as number of 
Panicle $/ \mathrm{m}^{2}$, straw and grain weight, gram $/ \mathrm{m}^{2}$, panicle length $\mathrm{cm}$, plant length $\mathrm{cm}$, number of grain/panicle and weight of 1000 grain (gram) were measured and calculated for each treatment at harvesting time for two wheat cultivars of (Gemmiza 11 and Shandweel) under study. Also, harvest index for each treatment under study was determined and calculated for two wheat cultivars of Gemmiza 11 and Shandweel under study. Harvest index (HI) used as an indicator for productive efficiency and it is could be defined as the ratio between the total weight of harvested grains and the total weight of biomass yield.

\subsection{Data analysis}

The results were analyzed using the CoStat Version 6.400 win exe. software program. The treatment means were analyzed using split- split plot for analysis of variance ANOVA and significant differences between the means were determined by the LSD test. The differences were considered statistically significant when $\mathrm{P}<0.05$.

\section{RESULTS AND DISCUSSION}

\subsection{Soil micro-organism biological activity.}

Soil micro-organisms such as bacteria, fungi, actinomycetes and etc. play an important role for transform gaseous nitrogen to biologically available ammonium, which is consider as an important source of nitrogen in soil ecosystems. Therefore, the obtained results of the seedbed preparation systems, Anhydrous Ammonia and Urea fertilization levels and interaction effects between them were summarized and discussed as follows:

\section{a- Bacteria}

In general, the obtained results indicated that the highest and the lowest values of bacteria counting in soil were recorded for moderate and conventional seedbed preparation systems(MS and CS), respectively at any given fertilization levels and measuring time as shown in Fig.(1). However, the differences between values of bacteria counting in soil for each seedbed preparation system were found to be very lower at any given fertilization level. Also, the results cleared that the values of bacteria counting in soil were highly decreased when using A.A.1 or A.A.2 instead of urea fertilizer at any given seedbed preparation systems 
and measuring time. In other words the Anhydrous-Ammonia Injection to the soil with two applied levels of A.A.1 and A.A.2 decreased the total number of soil bacteria compared with urea application at planting time for any given seedbed preparation systems. However, the second level of A.A.2 was found very toxic for soil bacteria compared with A.A.1 at planting time and at any given seedbed preparation system. After 1 month of planting, the number of total soil bacteria was recovered and highly increased at any applied fertilizer levels and seedbed preparation systems compared with planting time. However when counting the total number of soil bacteria after wheat harvesting was found to be slightly decreased than 1 month after planting and still higher than at planting time.

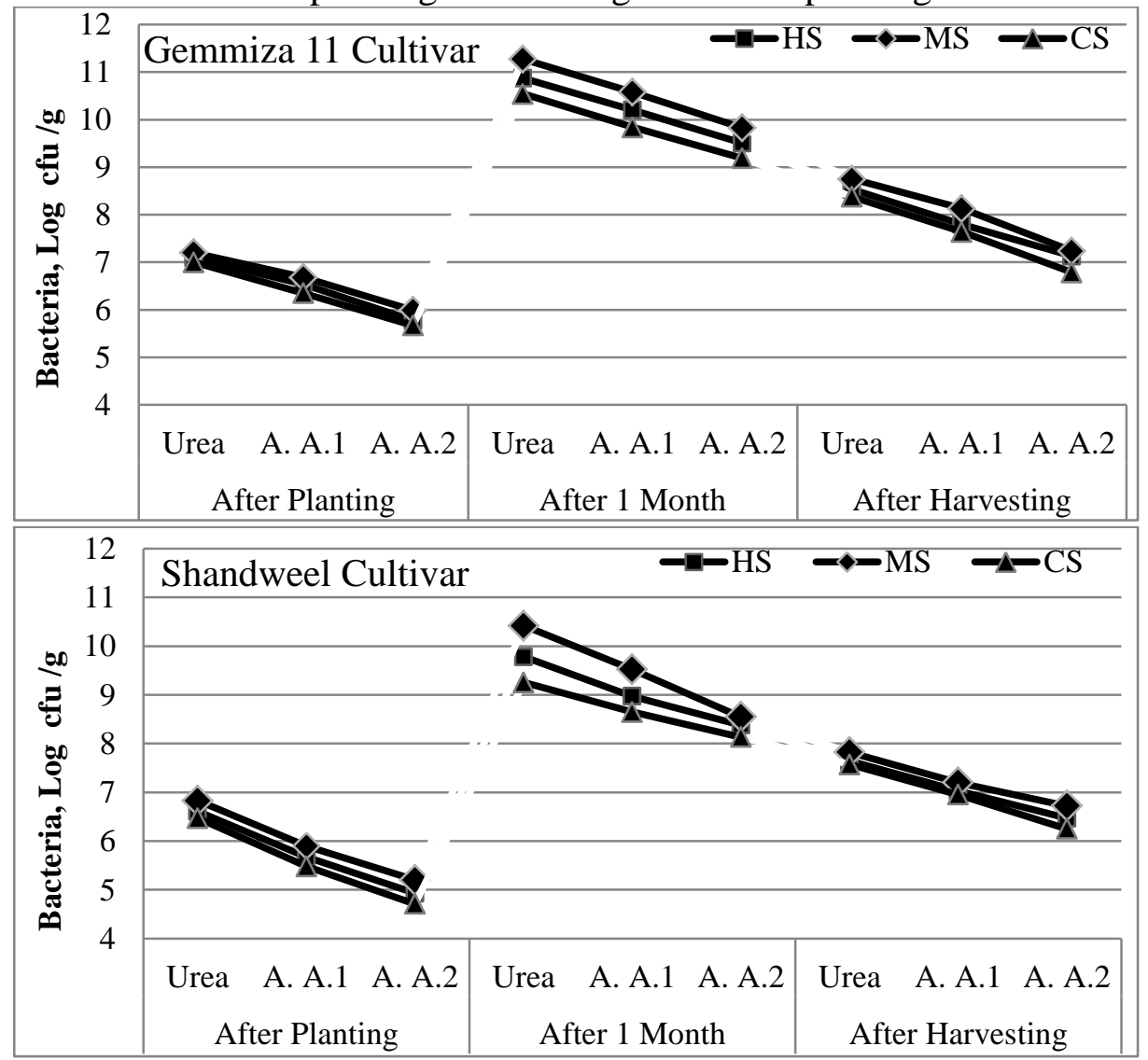

Fig.(1): Effect of different seedbed preparation systems and applied fertilizer levels on total soil bacteria.

The total number of bacteria in soil for urea fertilizer at different seedbed preparation systems HS, MS and CS at planting time were 7.10, 7.20 and 
7.00 Log cfu/g compared with A.A.1 fertilizer which gave 6.54, 6.68 and 6.35 Log cfu/g and 5.78, 5.99 and 5.67 Log cfu/g for A.A.2 fertilizer for Gemmiza 11 wheat cultivar, respectively. Also, the results illustrated that the response of Shandweel wheat cultivar was gave the same trends of bacteria counting in soil at any given seedbed preparation systems and applied fertilizer levels under study. However the total number was found to be slightly lower than that obtained for Gemmiza 11 wheat cultivar. The total number of bacteria in soil for urea fertilizer at different seedbed preparation systems HS, MS and CS at planting were 6.61, 6.83 and 6.47 Log cfu/g compared with A.A.1 fertilizer which gave 5.67, 5.90 and 5.48 Log cfu/g and 4.93, 5.20 and $4.71 \mathrm{Log} \mathrm{cfu} / \mathrm{g}$ for A.A.2 fertilizer respectively, for Shandweel wheat cultivar.

Data analysis results of variance for bacteria counting in soil under different seedbed preparation systems (HS, MS and CS) and applied fertilizer levels of a urea and Anhydrous-Ammonia (Urea, A.A.1 and A.A.2) under study showed that highly significant differences between applied fertilizer levels, significant differences between seedbed preparation systems and no significant differences between interaction between seedbed preparation systems and applied fertilizer levels at probability $5 \%$ for bacteria counting in soil at planting. The least significant difference (LSD) value between applied fertilizer levels was 0.082 however, the least significant difference (LSD) value between seedbed preparation systems was 0.203 .

However, after 1 month the results cleared highly significant differences between seedbed preparation systems, applied fertilizer levels and its interaction at probability $5 \%$ for bacteria counting. The least significant difference (LSD) value for seedbed preparation systems, and applied fertilizer levels were 0.101 and 0.053 respectively, at probability $5 \%$. The statistical analysis of variance after harvesting cleared that there was no significant differences between seedbed preparation systems, highly significant differences between applied fertilizer levels and no significant differences between its interaction. The least significant difference (LSD) value for fertilizer level was 0.071 at probability $5 \%$.

\section{b- Fungi}

Fungi represent one component of soil microorganisms which play critical roles in nutrient cycling and soil structure maintenance. The fungi 
have several beneficial effects on their host plants, such as support of nutrient uptake, enhanced resistance against drought or root pathogens (Heijden et al., 2015). The results of laboratory assay for counting fungi in soil indicated that the moderate seedbed preparation system, MS gave the highest values comparing with the conventional seedbed preparation system, CS which record the lowest values at any given fertilization levels and measuring time as shown in Fig.(2). However, the differences between values of fungi counting in soil for each seedbed preparation system were found to be very lower at any given fertilization level.

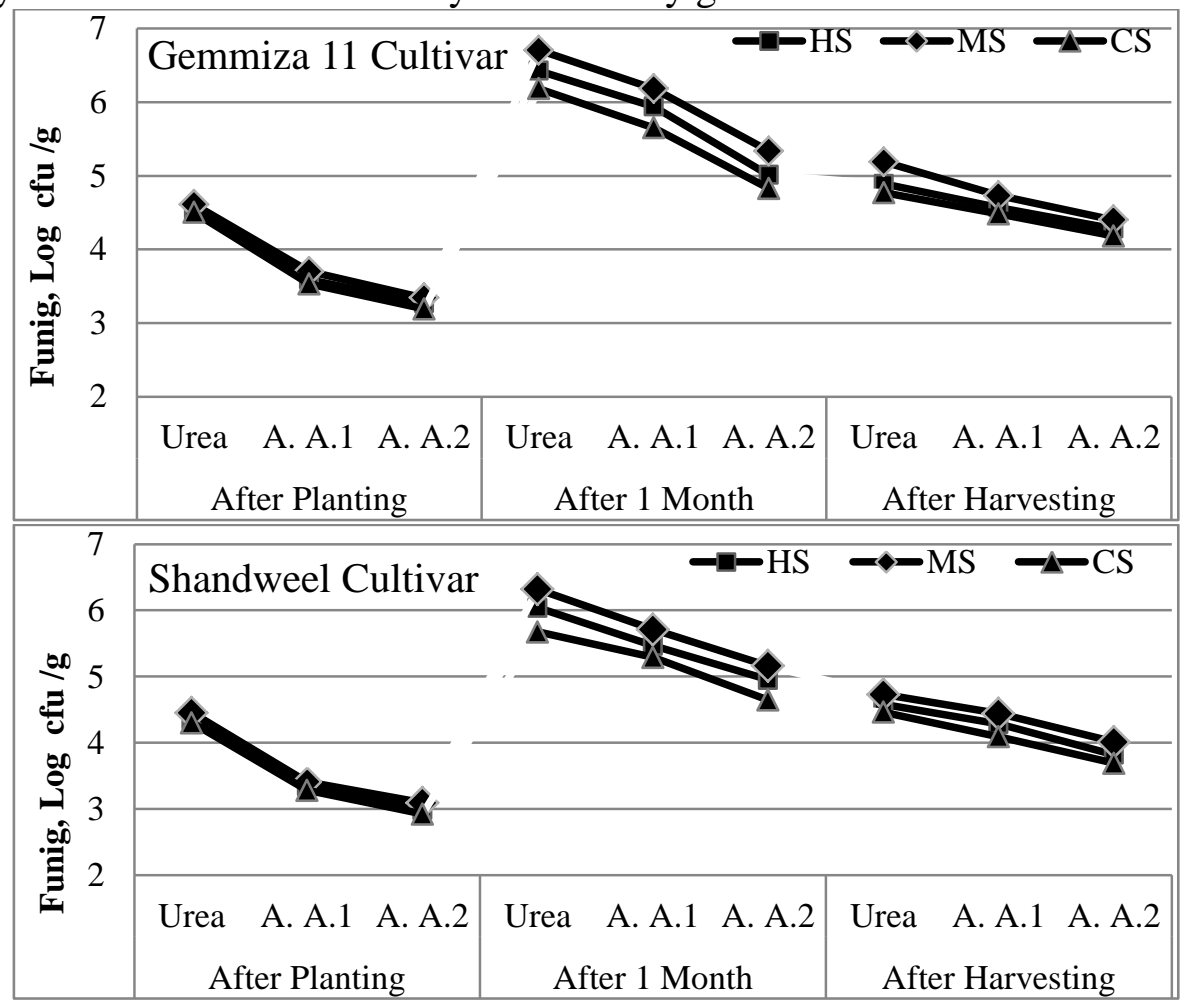

Fig.(2): Effect of different seedbed preparation systems and applied fertilizer levels on the total soil fungi.

As shown of the results illustrated in Fig.(2) it could be cleared that the Anhydrous-Ammonia Injection to the soil with two applied levels of A.A.1 and A.A.2 decreased the total number of soil fungi compared with urea application at planting time for any given seedbed preparation systems. However, the decrement percentage in total soil fungi was 
higher with the second level of A.A.2 compared with first level of A.A.1 at planting time and at any given seedbed preparation system. After 1 month of planting the soil fungi was recovered and highly increased under any given seedbed preparation systems and applied fertilizer levels compared with its values at planting time. However when counting the total number of soil fungi after wheat harvesting was found to be slightly decreased than 1 month after planting and still higher than at planting time. The total number of fungi in soil for urea fertilizer at different seedbed preparation systems HS, MS and CS at planting were 4.53, 4.61 and 4.50 Log cfu/g compared with A.A.1 fertilizer which gave 3.59, 3.70 and 3..53 Log cfu/g, while, it were 3.27, 3.37 and $3.19 \mathrm{Log} \mathrm{cfu} / \mathrm{g}$ for A.A. 2 fertilizer, respectively for Gemmiza 11 wheat cultivar.

Also, the results indicated that the response of Shandweel wheat cultivar was gave the same trends of fungi counting in soil at any given seedbed preparation systems and applied fertilizer levels under study. However the total soil fungi number was found to be slightly lower than that obtained for Gemmiza 11 wheat cultivar. The total number of fungi in soil for urea fertilizer at different seedbed preparation systems HS, MS and CS at planting were $4.35,4.45$ and $4.30 \mathrm{Log}$ cfu/g compared with A.A.1 and A.A.2 fertilizer which gave 3.34, 3.41, 3.28, 2.98, 3.09 and $2.92 \log$ cfu/g respectively, for Shandweel wheat cultivar.

Data analysis results of variance for the total soil fungi under different seedbed preparation systems (HS, MS and CS), applied fertilizer levels of urea and Anhydrous-Ammonia (Urea, A.A.1 and A.A.2) and the interaction between them showed that significant differences between seedbed preparation systems, highly significant differences between applied fertilizer levels, and no significant differences between its interaction at probability 5\%. The least significant difference (LSD) value between seedbed preparation systems and applied fertilizer levels were 0.059 and 0.046 respectively. However, after 1 month the results cleared significant highly differences between seedbed preparation systems, applied fertilizer levels and no significant differences between its interactions at probability 5\%. The least significant difference (LSD) value for seedbed preparation systems, and applied fertilizer levels were 0.0585 and 0.0665 respectively, at probability $5 \%$. Statistical analysis of 
variance after harvesting cleared that there was highly significant differences between seedbed preparation systems, applied fertilizer levels and no significant differences between its interactions. The least significant difference (LSD) value for seedbed preparation systems and applied fertilizer levels were 0.071 and 0.046 respectively, at probability $5 \%$.

\section{c- Actinomycetes}

The actinomycetes are a group of soil microorganisms which are mineralize organic matter to increase soil fertility and agricultural production. The obtained results indicated that the highest and the lowest values of soil actinomycetes were recorded for moderate and conventional seedbed preparation systems (MS and CS), respectively at any given applied fertilizer levels as shown in Fig.(3). However, the differences between values of soil actinomycetes for each seedbed preparation system were found to be very lower than values obtained between applied fertilizer levels at any given estimation time.

As shown in data illustrated Fig.(3) it could be cleared that the Anhydrous-Ammonia Injection to the soil with two applied levels of A.A.1 and A.A. 2 decreased the total number soil actinomycetes compared with urea application at planting time for any given seedbed preparation systems. However, the highest decrement percentages in the total soil actinomycetes were found with the second level of A.A.2 at planting time under any given seedbed preparation system. After 1 month of planting, the soil actinomycetes were recovered and highly increased at any applied fertilizer levels and seedbed preparation systems compared with at planting time. However when counting the total number of soil actinomycetes after wheat harvesting was found to be slightly decreased than 1 month after planting and still higher than at planting time.

The total number of soil actinomycetes when applying urea fertilizer to the soil were 4.31, 4.54 and 4.22 Log cfu/g compared with 3.86, 3.92 and 3.67 Log cfu/g when applying A.A.1, while, it were 3.16, 3.27 and 3.00 Log cfu/g, when applying A.A.2 under different seedbed preparation systems of HS, MS and CS, respectively at planting time for Gemmiza 11 wheat cultivar. Also, the results indicated that the response of Shandweel wheat cultivar was gave the same trends of actinomycetes counting in soil 
at any given seedbed preparation systems and applied fertilizer levels under study. However the total fungi number was found to be slightly lower than that obtained for Gemmiza 11 wheat cultivar.

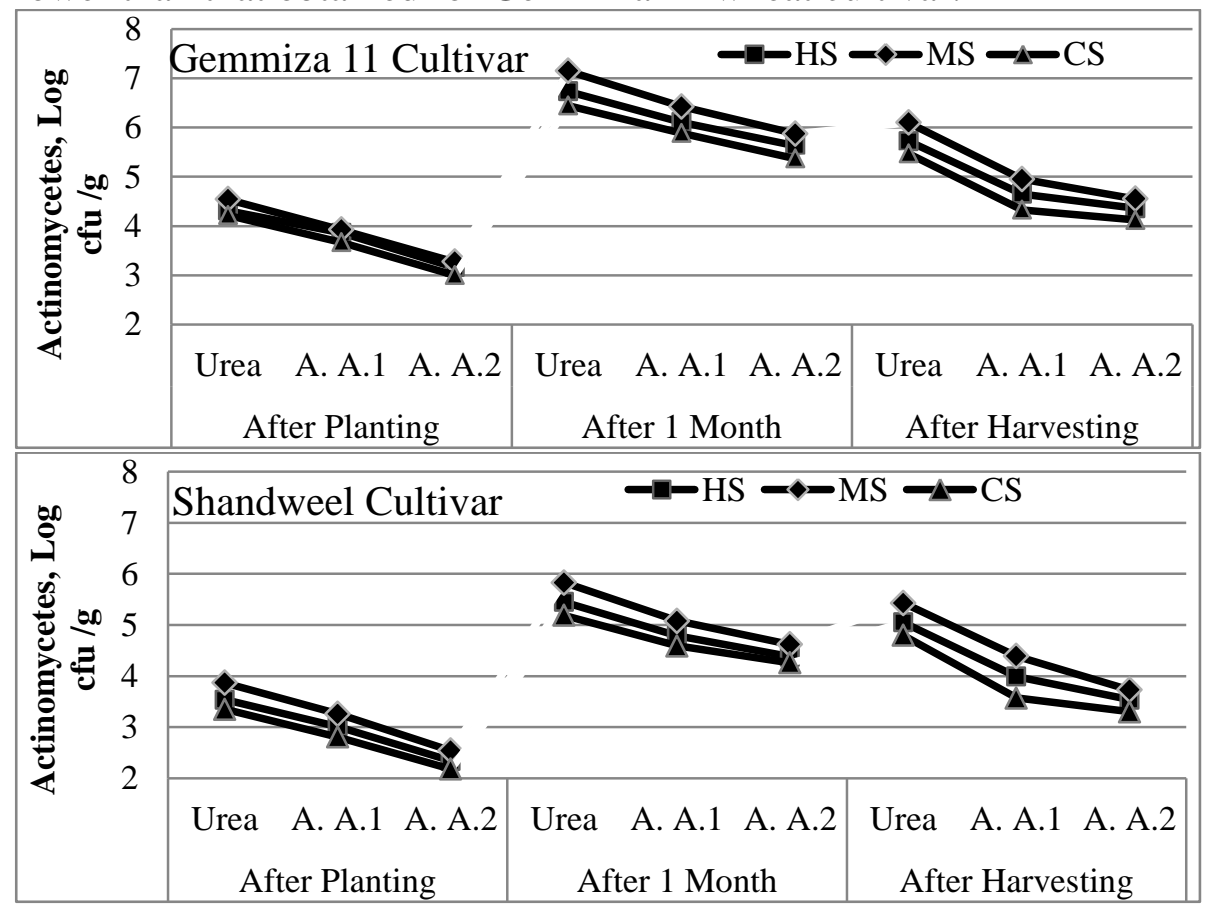

Fig.(3): Effect of different seedbed preparation systems and applied fertilizer levels on total soil actinomycetes.

Data analysis results of variance for soil actinomycetes counting under different seedbed preparation systems (HS, MS and CS), applied fertilizer levels of urea \& Anhydrous-Ammonia (Urea, A.A.1 and A.A.2) and the interaction between them showed a highly significant differences between applied fertilizer levels, no significant differences between seedbed preparation systems and significant differences between its interaction at probability 5\% for soil actinomycetes counting at planting. The least significant difference (LSD) value between applied fertilizer levels and seedbed preparation systems are 0.044 and 0.326 respectively. However, after 1month the results cleared significant differences between seedbed preparation systems, highly significant differences between applied fertilizer levels and highly significant differences between its interactions at probability $5 \%$ for soil actinomycetes counting. The least significant difference (LSD) value for applied fertilizer levels and seedbed 
preparation systems are 0.211 and 0.428 respectively, at probability $5 \%$. The statistical analysis of variance after harvesting cleared that there was no significant differences between seedbed preparation systems, applied fertilizer levels and its interaction.

\subsection{Plant growth activity.}

Nitrogen is a basically important element in biologically activity and nutrient cycling processes. It is containing constituents of organic molecules often confer bioactivity to these molecules (Hossien and Gooshchi, 2013). Therefore, the nitrogen content in soil and in a wheat plant was taken as indicators for wheat plant growth activity under different seedbed preparation systems (HS, MS and CS), applied fertilizer levels of urea and Anhydrous-Ammonia (Urea, A.A.1 and A.A.2) and the interaction between them in this investigation. The obtained results were summarized and discussed as follows:

\section{a- Nitrogen content in soil}

In general, the nitrogen content in the soil was highly affected with applied fertilizer levels of urea and Anhydrous-Ammonia (Urea, A.A.1 and A.A.2) after planting directly. The treatments were injected with 93.75 kg N/fed of Anhydrous-Ammonia gave the highest values of the nitrogen content in the soil followed by the treatments were injected with $75 \mathrm{~kg} \mathrm{~N} / \mathrm{fed}$ of Anhydrous-Ammonia and treatments applied with $75 \mathrm{~kg}$ $\mathrm{N} /$ fed of urea $(46.5 \% \mathrm{~N})$ under any given seedbed preparation systems when estimated after planting directly in this investigation. However, the values of nitrogen content in the soil after 1 month of planting and after harvesting were highly decreased compared with that values after planting directly.

Also, the obtained results illustrated in Fig. (4) indicated that, the moderate seedbed preparation system, MS gave the highest values of nitrogen content in the soil flowed by heavy seedbed preparation system, HS and the conventional seedbed preparation system, CS, after planting directly. However, this trend was changed after 1month of planting and after harvesting. The moderate seedbed preparation system, MS recorded the lowest values of nitrogen content in the soil flowed by heavy seedbed preparation system, HS and the conventional seedbed preparation system, CS. However, the differences between values of nitrogen in soil for each 
seedbed preparation system were found to be very lower at any given fertilization level. Nitrogen content in soil for Gemmiza 11 wheat cultivar after 1 month of planting under different applied fertilizer levels of urea, A.A.1 and A.A.2 were 14.00, 13.40, and 14.50 ppm respectively, under heavy seedbed preparation system, HS and 21.25, 20.38 and $22.18 \mathrm{ppm}$ respectively, under moderate seedbed preparation system, MS and 32.05, 31.40 and $33.36 \mathrm{ppm}$ respectively, under conventional seedbed preparation system, CS. However, it were, 13.30, 12.90 and $13.56 \mathrm{ppm}$ respectively, under heavy seedbed preparation system, HS and 20.55, 19.75 and $21.20 \mathrm{ppm}$ respectively, under moderate seedbed preparation system, MS and 31.49, 30.99 and 32.27 ppm respectively, under conventional seedbed preparation system, CS for Shandweel wheat cultivar at the same estimation time.

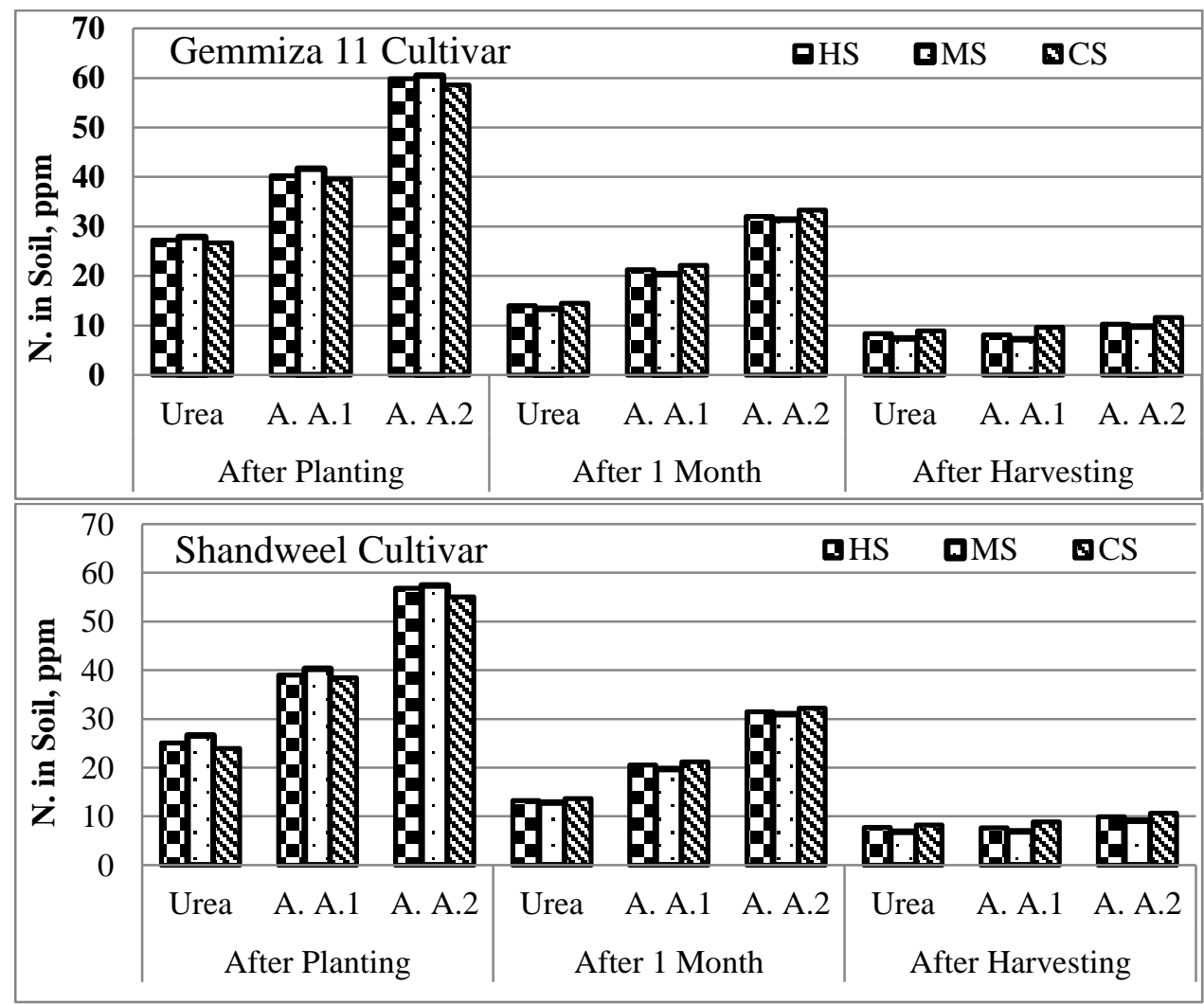

Fig. (4): Effect of different seedbed preparation systems and applied fertilizer levels on nitrogen content in soil. 
Data analysis results of variance for nitrogen content in soil under different seedbed preparation systems (HS, MS and CS), applied fertilizer levels of urea and Anhydrous-Ammonia (Urea, A.A.1 and A.A.2) and the interaction between them showed highly significant differences between applied fertilizer levels, significant differences between seedbed preparation systems and no significant differences between its interaction at probability $5 \%$ after planting directly. The least significant difference (LSD) value between fertilizer levels and seedbed preparation systems were 0.33 and 0.91 respectively. However, after 1 month the results cleared no significant differences between seedbed preparation systems, applied fertilizer levels and its interaction at probability 5\%. The statistical analysis of variance for nitrogen in soil after harvesting cleared that there was highly significant differences between seedbed preparation systems, applied fertilizer levels and its interaction. The least significant difference (LSD) value for seedbed preparation systems and fertilizer level were 0.71 and 0.059 respectively, at probability $5 \%$.

\section{b- Nitrogen content in wheat plant.}

Laboratory analysis of nitrogen content on plants indicated that the first level of applied fertilizer, urea achieved the lowest values of nitrogen content in plant under any given seedbed preparation system for both two wheat cultivars under study. While, the second level of applied Anhydrous-Ammonia fertilizer recorded the highest values of nitrogen content in plant under any given seedbed preparation system for both two wheat cultivars under study. The seedbed preparation system of MS recorded high values for nitrogen content in plant comparing with seedbed preparation systems of HS and CS under different levels of applied fertilizer for Gemmiza 11cultivar. However, the seedbed preparation of CS achieved the highest values of nitrogen content in plant comparing with seedbed preparation systems of HS and MS under different levels of fertilizer for Shandweel cultivar due to the Shandweel cultivar voracity of nitrogen which deposited in plant.

The highest value of nitrogen content $0.60 \%$ was obtained under seedbed preparation system of MS and applied fertilizer level A.A.2 for wheat cultivar Gemmiza 11 and the lowest value of nitrogen content was $0.25 \%$ 
under soil preparation system CS and applied fertilizer level urea for wheat cultivar Shandweel.

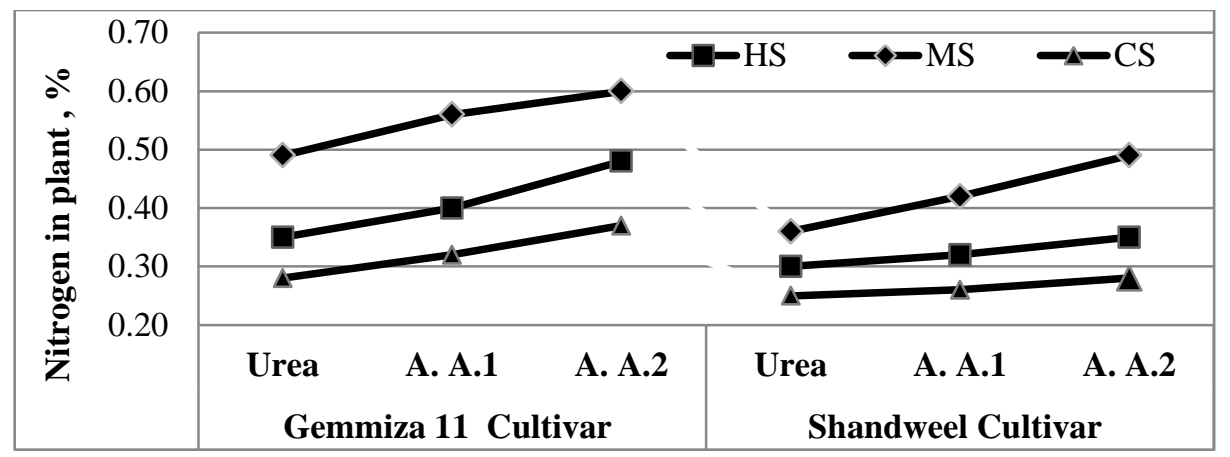

Fig.(5): Effect of different seedbed preparation systems and applied fertilizer levels on nitrogen content in wheat plant.

The statistical analysis results of variance for nitrogen content in plant under different seedbed preparation systems (HS, MS and CS), applied fertilizer levels of urea and Anhydrous-Ammonia (Urea, A.A.1 and A.A.2) and the interaction between them showed significant differences between seedbed preparation systems, highly significant differences between applied fertilizer level and its interaction at probability 5\%. The least significant difference (LSD) value for fertilizer levels and seedbed preparation systems were 0.012 and 0.102 respectively.

\subsection{Crop yield and its components.}

The differences in yield components for both wheat cultivars of Gemmiza 11 and Shandweel, Panicle $/ \mathrm{m}^{2}$, panicle length, $\mathrm{cm}$; plant length, $\mathrm{cm}$; number of grain/panicle, weight of 1000 grain, g; grain weight, g/ $\mathrm{m}^{2}$; straw weight, $\mathrm{g} / \mathrm{m}^{2}$; and its statistical analysis of variance under different study treatments are listed in Table (2). The obtained data cleared that seedbed preparation system of MS with applied fertilizer level of A.A.1 recorded the highest values of total grain yield 29.6 and $24.8 \mathrm{Ardb} / \mathrm{Fed}$ for Gemmiza 11 and Shandweel wheat cultivars, respectively comparing with two other seedbed preparation systems of HS and CS and applied fertilizer levels of Urea and A.A.2. However, the seedbed preparation system of CS under applied fertilizer level of A.A.2 recorded the lowest values of total grain yield 13.7 and $12.4 \mathrm{Ardb} / \mathrm{Fed}$ for Gemmiza 11 and Shandweel wheat cultivars, respectively comparing with two other 
seedbed preparation systems of HS and MS and applied fertilizer levels of Urea and A.A.1.

Table (2): Total grain yield and its component for Gemmiza 11and Shandweel wheat cultivars.

\begin{tabular}{|c|c|c|c|c|c|c|c|c|c|c|c|}
\hline \multicolumn{12}{|c|}{ Gemmiza 11 wheat cultivar } \\
\hline$\frac{\Xi}{0}$ & 预 & 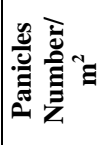 & 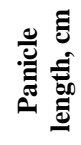 & 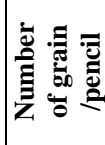 & 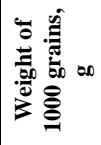 & 践 & 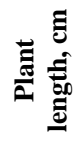 & 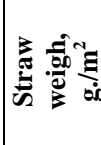 & 焉 & 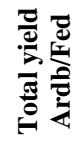 & 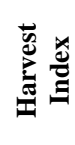 \\
\hline \multirow{3}{*}{ HS } & Urea & 172 & 14.20 & 65.43 & 48.66 & 547.6 & $\mathbf{9 7 . 3}$ & 755.3 & 1302.9 & 15.3 & 0.42 \\
\hline & A.A.1 & 187 & 16.03 & 82.70 & 55.71 & 861.5 & 100.9 & 786.2 & 1647.7 & 24.1 & 0.52 \\
\hline & A.A2 & 198 & 15.74 & 71.50 & 50.26 & 711.5 & 102.5 & 911.5 & 1623.0 & 19.9 & 0.44 \\
\hline \multirow{3}{*}{ MS } & Urea & 177 & 14.38 & 74.20 & 50.31 & 660.7 & 98.9 & 812.6 & 1473.3 & 18.5 & 0.45 \\
\hline & A.A.1 & 190 & 16.56 & 98.30 & 56.61 & 1057.3 & 101.7 & 882.4 & 1939.7 & 29.6 & 0.55 \\
\hline & A.A.2 & 205 & 16.34 & 77.30 & 54.39 & 861.9 & 106.5 & 1021.2 & 1883.1 & 24.1 & 0.46 \\
\hline \multirow{3}{*}{ CS } & Urea & 170 & 13.50 & 64.00 & 44.91 & 488.6 & 95.4 & 729.4 & 1218.0 & 13.7 & 0.40 \\
\hline & A.A.1 & 180 & 15.90 & 82.30 & 54.26 & 803.8 & 94.2 & 753.6 & 1557.4 & 22.5 & 0.52 \\
\hline & A.A.2 & 189 & 15.06 & 70.50 & 48.08 & 640.6 & 101.9 & 891.8 & 1532.4 & $\mathbf{1 7 . 9}$ & 0.42 \\
\hline \multicolumn{12}{|c|}{ Shandweel wheat cultivar } \\
\hline \multirow{3}{*}{ HS } & Urea & 170 & 11.7 & 70.3 & 40.81 & 487.7 & 77.1 & 759.1 & 1246.8 & 13.7 & 0.39 \\
\hline & A.A.1 & 189 & 13.9 & 78.1 & 48.06 & 709.4 & 94.5 & 865.6 & 1575.0 & 19.9 & 0.45 \\
\hline & A.A.2 & 201 & 13.2 & 73.5 & 42.02 & 620.8 & 93.9 & 897.7 & 1518.5 & 17.4 & 0.41 \\
\hline \multirow{3}{*}{ MS } & Urea & 179 & 12.1 & 79.1 & 42.91 & 607.6 & 86.1 & 821.5 & 1429.1 & 17.0 & 0.43 \\
\hline & A.A.1 & 197 & 14.14 & 85.3 & 52.76 & 886.6 & 94.9 & 990 & 1876.6 & 24.8 & 0.47 \\
\hline & A.A. 2 & 204 & 13.5 & 77.5 & 45.91 & 725.8 & 95.1 & 1077 & 1802.8 & 20.3 & 0.40 \\
\hline \multirow{3}{*}{ CS } & Urea & 160 & 11.6 & 70.5 & 39.31 & 443.4 & 76.1 & 720 & 1163.4 & 12.4 & 0.38 \\
\hline & A.A.1 & 179 & 13.7 & 75.7 & 45.11 & 611.3 & 94.2 & 770 & 1381.3 & 17.1 & 0.44 \\
\hline & A.A.2 & 193 & 13.1 & 71.5 & 40.61 & 560.4 & 94.1 & 810 & 1370.4 & 15.7 & 0.41 \\
\hline \multicolumn{2}{|c|}{$\begin{array}{c}\text { Seedbed prep. } \\
\text { system }\end{array}$} & $*$ & ns & * & $*$ & $* *$ & ns & ns & $* *$ & $*$ & ns \\
\hline \multicolumn{2}{|c|}{$\begin{array}{c}\begin{array}{c}\text { Fertilizer } \\
\text { levels }\end{array} \\
\end{array}$} & $* * *$ & $* * *$ & $* * *$ & $* * *$ & $* * *$ & $* * *$ & $* * *$ & $* * *$ & $* * *$ & $* * *$ \\
\hline \multicolumn{2}{|c|}{ Cultivars } & ns & $* *$ & ns & ** & $* *$ & $* *$ & ns & $*$ & $*$ & $*$ \\
\hline \multicolumn{2}{|c|}{ SB.P.S* F.L. } & ns & ns & ns & $*$ & $* *$ & ns & $* * *$ & $* * *$ & $*$ & $* * *$ \\
\hline \multicolumn{2}{|c|}{$\begin{array}{l}\text { LSD for } \\
\text { SB.P.S }\end{array}$} & 8.197 & 0.751 & 5.657 & 2.053 & 30.028 & 4.11 & 0.775 & 102.83 & 2.269 & $\mathbf{0 . 0 3 3}$ \\
\hline \multicolumn{2}{|c|}{ LSD for F.L. } & 1.84 & 0.125 & 2.038 & 0.543 & 19.511 & 2.27 & 0.076 & 13.151 & 0.753 & 0.019 \\
\hline \multicolumn{2}{|c|}{$\begin{array}{l}\text { LSD for } \\
\text { cultivars }\end{array}$} & - & 0.613 & - & 1.676 & 24.518 & - & - & 88.86 & 1.853 & 0.027 \\
\hline
\end{tabular}

In regards of yield components for Gemmiza 11 wheat cultivar, the results summarized in Table (2) indicated that the Seedbed preparation of 
MS with applied fertilizer level of A.A.1 recorded the highest values for panicles number $/ \mathrm{m}^{2}$; number of grains/panicle; weight of 1000 grain, panicle length; grains weight $/ \mathrm{m}^{2}$; plant length and straw weight $/ \mathrm{m}^{2}$ in comparison with two others seedbed preparation systems of HS and CS and applied fertilizer levels of Urea and A.A.2.

However, the Seedbed preparation of CS with applied fertilizer level of A.A.2 recorded the lowest values for panicles number $/ \mathrm{m} 2$; number of grains/panicle; weight of 1000 grain, panicle length; grains weight $/ \mathrm{m} 2$; plant length and straw weight $/ \mathrm{m} 2$ in comparison with two others seedbed preparation systems of HS and MS and applied fertilizer levels of Urea and A.A.1.The same trends of yield components results were obtained for Shandweel wheat cultivar, however these values were found to be lower than that obtained for Gemmiza 11 wheat cultivar.

\subsection{Harvest index}

The obtained results of harvest index are illustrated in Fig.(6) and cleared that the Gemmiza 11wheat cultivar achieved the highest value of harvest index (0.55) comparing with that obtained for Shandweel wheat cultivar (0.47) under MS seedbed preparation system and A.A.1 applied fertilizer level. However, the lowest values of harvest index were 0.39 and 0.38 for Gemmiza 11 and Shandweel wheat cultivars, respectively under CS seedbed preparation system and Urea applied fertilizer level.

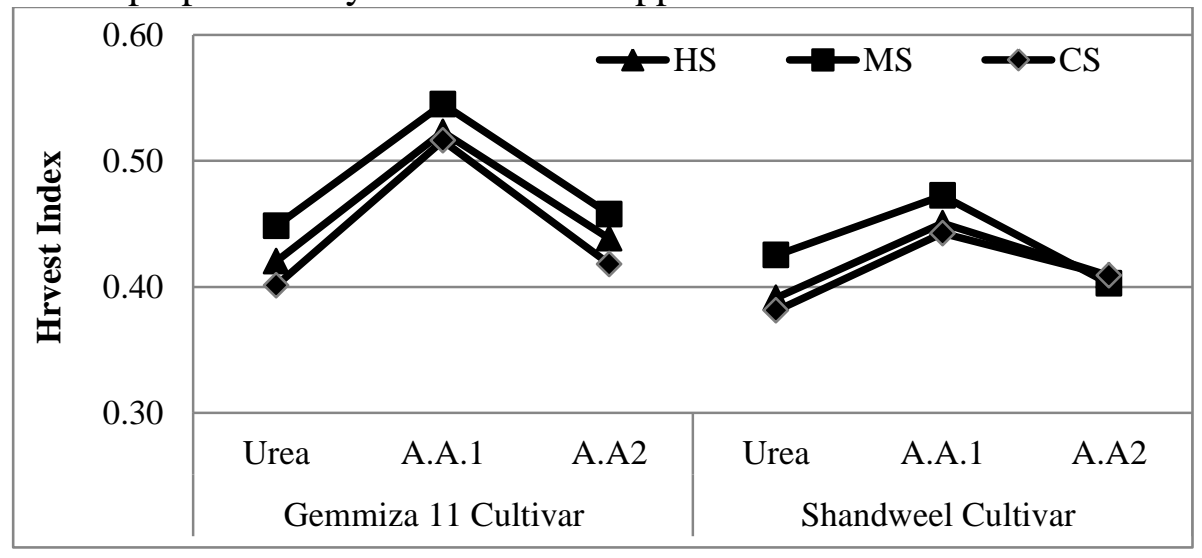

Fig. 6: Effect of different seedbed preparation systems and applied fertilizer levels on wheat crop index.

The statistical analysis results of variance for harvest index under different seedbed preparation systems (HS, MS and CS), applied fertilizer 
levels of urea and Anhydrous-Ammonia (Urea, A.A.1 and A.A.2) and the interaction between them showed no significant differences between seedbed preparation systems, highly significant differences between fertilizer level and its interaction at probability 5\%. The least significant difference (LSD) value for fertilizer levels and seedbed preparation systems were 0.019 and 0.033 respectively.

\section{CONCLUSIONS AND RECOMMENDATIONS}

From the previous results and discussion it could be concluded that:

- The obtained results indicated that there is a significant defect on the population and activity of soil micro-organisms after directly injection of Anhydrous-Ammonia to the soil, especially in the retention zone of ammonia around the point of injection. However the population of soil micro-organisms did not go to zero and this effect was found to be more lower with A. A.1 than that obtained with A. A.2 under any given seedbed preparation system and wheat cultivars.

- Applying MS seedbed preparation system improve the soil conditions which rapidly helped the population and biological activity of soil micro-organisms to recover and increase than that obtained with other two seedbed preparation systems using any given applied fertilizer levels and wheat cultivars under study.

- The population and activity of soil micro-organisms increased as the length of time increased compared with applied Urea fertilizer. Approximately, one month after A.A.1 injection, the populations of bacterial group were increased by an average of 57.8 and $58.6 \%$ while, the fungi group was increased by an average of 53.5 and $55.2 \%$ compared with 65.1 and $66.0 \%$ for actinomycetes group during growing Gemmiza 11 and Shandweel wheat cultivars, respectively.

- The highest values of nitrogen content were recorded in the soil under MS seedbed preparation system and applied fertilizer level of A.A.1 for both wheat cultivars under study.

- Using MS seedbed preparation system and applied fertilizer level of A.A.1 gave the highest values of the total grain yield of 18.5, 29.6 and 24.1 Ardb/Fed were obtained for Gemmiza wheat cultivars compared with 17, 24.8 and 20.3 Ardb/Fed.for Shandweel wheat cultivars under applied fertilizer levels of Urea, A.A.1 and A.A.2, respectively. 
- Finally, from all points mentioned above and analyses of yield and its components, the author recommended the wheat farmers in Egypt using MS seedbed preparation system and applied fertilizer level A.A.1 to get high wheat yield and maintain the soil in a good biological state.

\section{REFERENCES}

Abd El-Hmeed, I.M.; A.E. Omar (2006). Response of bread wheat to some fertilization treatments. In: The 31 st International Conference for Statistics, Computer Science and its Applications, pp. 1- 6.

Abdelkhalek A.A. ; R. Kh. Darwesh and Mona A.M. El-Mansoury (2015). Response of some wheat varieties to irrigation and nitrogen fertilization using ammonia gas in North Nile Delta region.Annals of Agricultural Science 60(2), 245-256

Al-Kaisi M. and D.Kwaw-Mensah (2007). Effect of Tillage and Nitrogen Rate on Corn Yield and Nitrogen and Phosphorus Uptake in a CornSoybean Rotation. American Society of Agronomy J. 99:15481558

Allen, O. N. (1959). Experiments in soil bacteriology.Burgess publishing Co. Minneopolis 15; Minnesota U S A.

Angus J. F.;V. V. S. R. Gupta; G. D. Pitson and A. J. Good (2014). Effects of banded ammonia and urea fertilizer on soil properties, and the growth and yield of wheat. Crop and Pasture Science. 65: 337-352.

Barry D.; G. Asamoa; E. Beauchamp; G. Watson And S. Mitchell (1990). Effect of Ammonia on Soil Properties and Relevance to Soil and Water Quality - D.., Ecologistics Ltd., Waterloo, ON 1-103

Benke M. B; T. B. Goh; R. Karamanos; N. Z. Lupwayi, and X. Hao (2012). Retention and nitrification of injected anhydrousNH3 as affected by soil Ph.Can. J. Soil Sci. 92: 589_598.

Black, A.C.; D.D. Evans; J.L. White; E.L. Ensminyer and E.F. Clark (1965). "Methods of Soil Analysis". Amer. Soc. Agro. Inc. Madison Wisconsin, USA. 
Britto D.T. and H.J. Kronzucker(2002). $\mathrm{NH}_{4}+$ toxicity in higher plants: a critical review. J. Plant Physiol. 159: 567 - 584.

Buunemann, E. K. and A. Mc Neil (2004). Impact of fertilizer on soil biota " soil Biology in agriculture" proceeding of a workshop on current researcher into soil biology in agriculture. Ed. R. LinesKelly Tomworth, NSW. Department of primary Industries. p 64-71.

Chapman, H.D. and P. F. Pratt (1961). Methods of Analysis for Soils, Plants and Waters Univ. California, Div. of Agric. Sci.

Clapperton, J. (2008).The real dirt on no tillage. No-Till on the Plains, Wamego,KS.Availableathttp://www.notill.org/KnowledgeBase/03_ realdirt_Clapperton.pdf

Coyne Mark S. and R. Mikkelsen (2015). Soil Microorganisms Contribute to Plant Nutrition and Root Health, Better Crops, Vol. 99 No.1, page $18-20$

Cramer M.D. and O.A.M Lewis (1993). The influence of nitrate and ammonium nutrition on the growth of wheat (Triticumaestivum) and maize(Zea mays) plants. Annals Bot. 72:359 - 365.

Gajda A.M. (2008). Effect of different tillage systems on some microbiological properties of soils under winter wheat. Int. Agrophysics, 22, 201-208.

Gajda A.M. ; B. Przewloka, and K. Gawryjolek (2013). Changes in soil quality associated with tillage system applied. Int. Agrophysics 8, 24-100

Gerendas J. ; Z Zhu. ; R. Bendixen Ratcliffe and B. Sattelmacher (1997). Physiologicaland biochemical processes related to ammonium toxicity in higher plants. J. Plant Nutr. Soil Sci. 160: 2, 239 - 251.

Gregor E. and C.Emmerling (2009). Impact of five different tillage systems on soil organic carbon content and the density, biomass, and community composition of earthworms after a ten year period

Gupta V.S.R.V. (2016). Biological factors influence N mineralization from soil organic matter and crop residues in Australian cropping 
systems. Proceedings of the 2016 International Nitrogen Initiative Conference,"Solutions to improve nitrogen use efficiency for the world", 4-8 December 2016, Melbourne, Australia.

Heijden V. D. ; M.G.A. Martin; F. Selosse; M.A. Sanders, I.R. (2015). Mycorrhizal ecology and Evolution: the past, the present, and the future. New Phytologist.

Hossein S. and F.Gooshchi (2013). Effects of Azotobacter and Nitrogen Chemical Fertilizer on Yield and Yield Components of Wheat. World Appl. Sci. J., 21 (8): 1176-1180

Jackson, M.L. (1967). Soil Chemical Analysis. Prentice-Hall, India, New Delhi,pp. 183-203.

Kumar S.; S. Chaudhuri and S.K. Maiti (2013). Soil Dehydrogenase Enzyme Activity in Natural and Mine Soil - A Review, Middle-East Journal of Scientific Research 13 (7): 898-906.

Lupwayi N. ; C. Hamel and T. Tollefson (2010). Soil Biology of the Canadian Prairies, Agricultural Soils of the Prairies Volume 3:16-24

Mahmoud, M.R. ; M. Abd, El-Warth and S.F. Mansour, (2006). Effect of biotechnologies on improving some properties of salt affected soils and its wheat production. Egypt J. Appl. Sci. 21, 332-351.

Marschner H. (1995). Mineral nutrition of higher plants. Academic Press London, GB. pp.889.

Mehrer I. and H. Mohr (1989).Ammonium toxicity: description of the syndrome in Sinapisalba and the search for its causation. Physiol. Plant. 77:545 -554.

Mijangos I., R. P'erez, I. Albizu and C. Garbisu (2006). Effects of fertilization and tillage on soil biological parameters. Enzyme and Microbial Technology 40:100-106.

Miller A.J. and M.D. Cramer (2004). Root nitrogen acquisition and assimilation. Plant Soil 274: 1-36. 
Sawyer J. (2010). Soil Fertility. Agronomy Extension Soil Fertility Web Site http://www.agronext.iastate.edu/soilfertility/, IOWA STATE UN.

Vitosh M. L., (2017) what happens to anhydrous ammonia in soil, MSU Crop and Soil Sciences Department. Web Site http://www. fieldcrop.msu.edu/...ts/Anhydrous Ammonia in soil.pdf

\section{الملخص العربي \\ تأثير حقن الأمونيا السائلة علي النشاط الحيوي للنبات

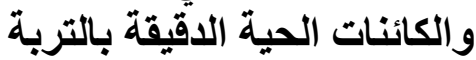

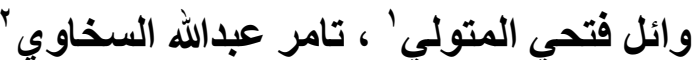

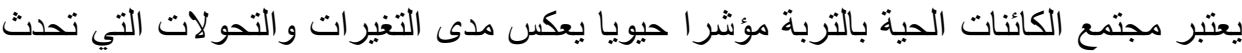

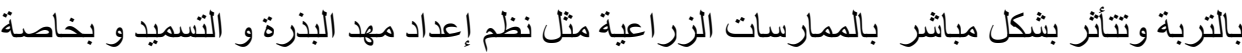

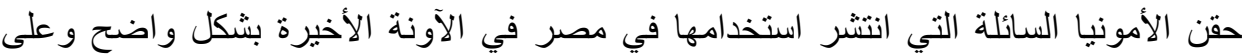
المستوى التطبيقي. ولهذا كان الهدف العام من هذا الدراسة هو تقدير تأثير حقن الأمونبا السائلة

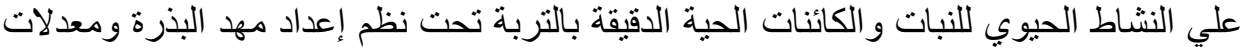

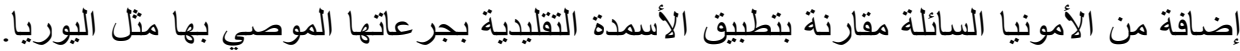

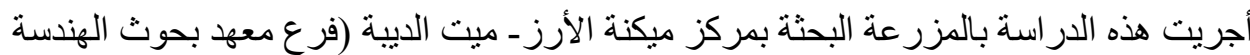

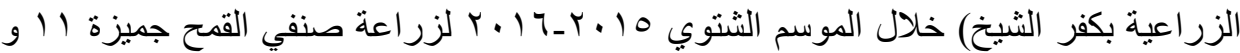

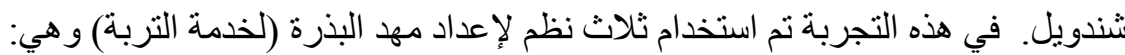

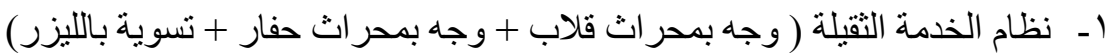

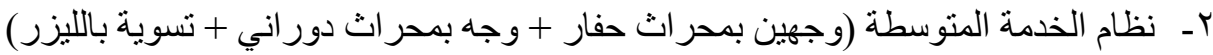

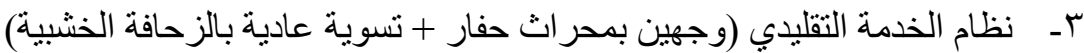

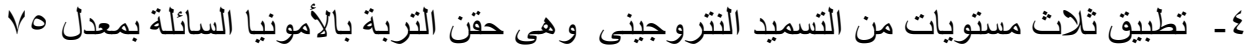

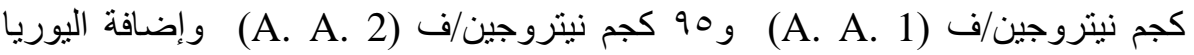

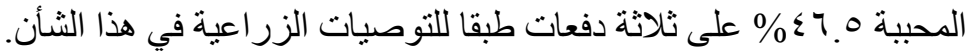

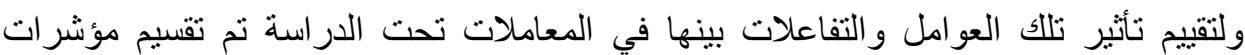

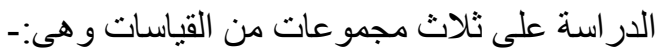
- دراسة التأثير المباشر على عدد الكائنات الحية بالتربة كمؤشر للنشاط الحيوي بالتربة

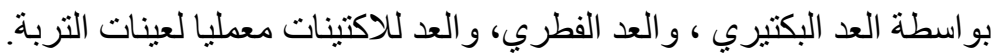
- تقدير نسبة النتروجين في التربة و النبات.

\footnotetext{
1 باحث بمعهد حوث الهندسة الزراعية ـ مركز البحوث الزراعية

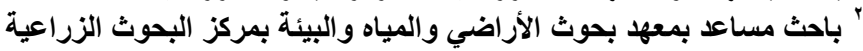


تقدير الإتتاجية الكلية للمحصول ،مكونات المحصول ودليل الحصاد كمؤشر للتأثير المبانشر

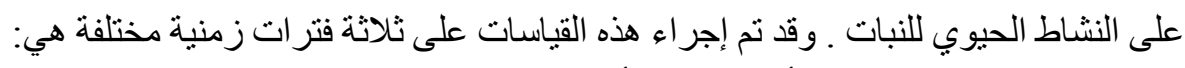

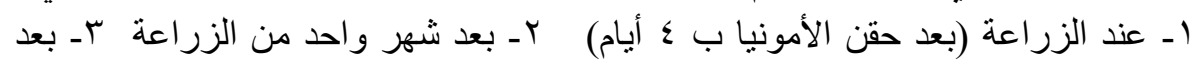

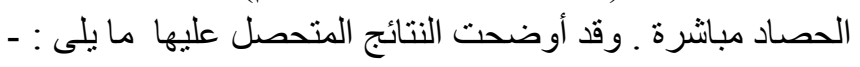

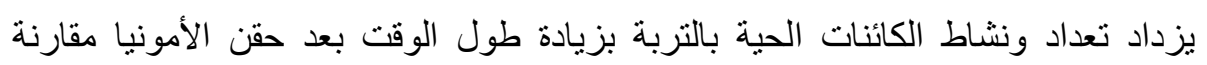

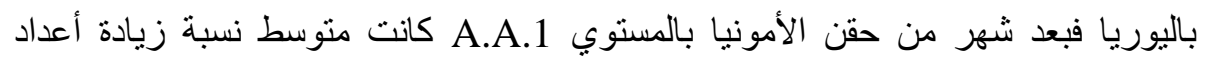

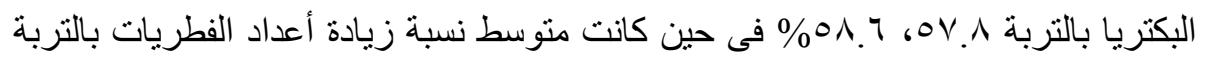

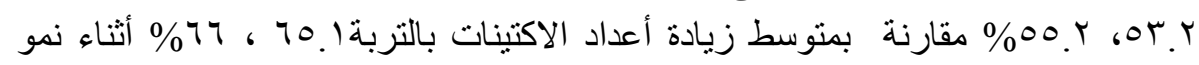

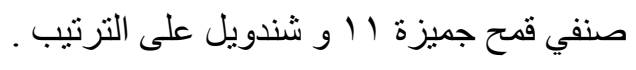

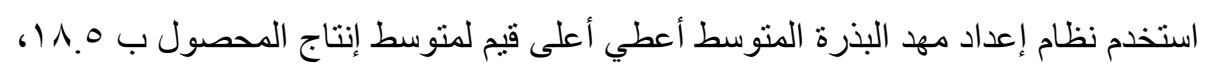

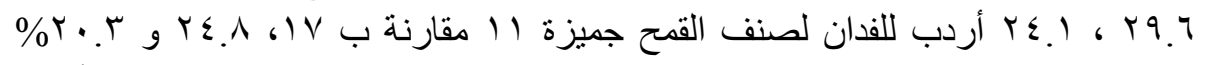

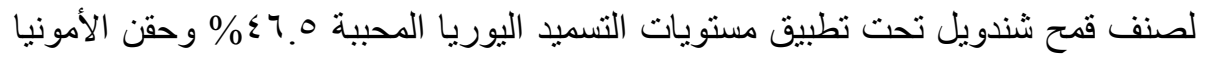

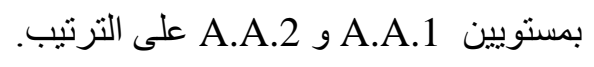

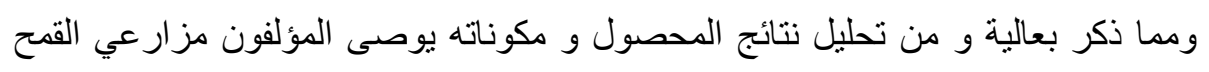

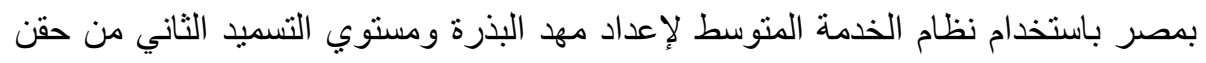

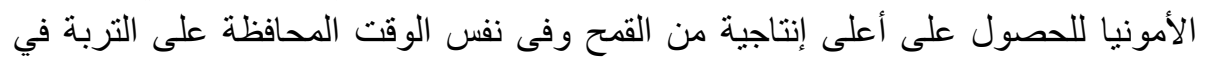
حالة بيولوجية جيدة 